\title{
Molecular Characterization of Riau's Mascot Flora (Oncosperma tigillarium)
}

\author{
Desti $^{* *}$, Fitmawati ${ }^{2}$, Putri Ade Rahma Yulis ${ }^{3}$, Mayta Novaliza Isda ${ }^{2}$ \\ ${ }^{I}$ Department of Biology Education, Faculty of Education, Universitas Islam Riau. Jl. Kaharuddin Nasution No. \\ 113 Marpoyan 28284, Pekanbaru, Indonesia. Tel. 0761-674674 Fax. 0761-674834 \\ ${ }^{2}$ Department of Biology Faculty of Mathematics and Natural Sciences, Universitas Riau. Kampus Bina Widya \\ Km 12,5 Simpang Baru Pekanbaru 28293, Indonesia. Tel. 0761-63272. Fax, : 0761-566821 \\ ${ }^{3}$ Department of Chemistry Education, Faculty of Education, Universitas Islam Riau. Jl. Kaharuddin Nasution
}

Corresponding author's e-mail address: destibio@edu.uir.ac.id

\begin{abstract}
This research was aims to find out about the molecular characterization of the Nibung plant (Oncosperma tigillarium). It has been conducted in the Biology Laboratory. The results of DNA isolation were tested to determine the quality of DNA that has been isolated. DNA purity was determined based on A260/A280 comparison values were tested using a nanodrop spectrophotometer (Sambrook et al. (1989) method. The quality of DNA from isolation was influenced by several factors such as the condition of the leaf sample used, the length of time of grinding, the phenolic content of the sample, the process of taking the supernatant solution and others. In this study, these factors were seen to significantly affect the quality of the DNA isolated. Also, DNA fragments generated from the isolation process are large, which indicates the large concentration of DNA produced. Although many DNA bands smear they still have clear DNA bands. Overall, the DNA isolation method based on the Doyle Doyle (1987) method in this study is applied to Nibung plants which is used as Riau's Province mascot flora.
\end{abstract}

Keywords: DNA isolation, Oncosperma tigillarium, Doyle and Doyle method.

\section{INTRODUCTION}

Nibung (Oncosperma tigillarium) is a flora mascot plant in Riau Province. This plant has many uses and has been widely used by the people of Riau, especially in the coastal areas of Riau. However, although it has been widely used by the community, Riau people themselves many do not know that the Nibung plant is a plant that is used as the mascot of the flora where it lives.

Our previous research showed that the characterization of the morphological of nibung plants was observed by using the instrument to observe the sample of nibung plants in the Bengkalis District, Riau Province. Several studies that have been carried out previously have obtained morphological and anatomical characterization of the stems of nibung plants in Riau Province, as well as their development for research-based teaching materials in the Biology Education Study Program FKIP Riau Islamic University [1]. Therefore, to get overall character information, we need a characterization activity at the molecular level. The use of molecular markers 
is expected to provide a description and results of characterization with high accuracy. One of them is by using DNA fragment hybridization results with DNA markers that amplify DNA fragments using a Polymerase Chain Reaction (PCR) machine.

On the other hand, the characterization of the molecular study of nibung (O. tigillarium) is expected to provide information about all the characters. So that it can help in the effort of development and conservation of plants nibung for the future. The information on the molecular characterization of nibung in Riau Province is still not there. Therefore, the activities of the characterization in Riau Province nibung are very important to observe. The study aims to obtain information about how the results of the molecular characterization of nibung plants are used as a mascot of the flora of Riau Province. This description includes a description of the procedure for the isolation of nibung DNA, and the factors that influence it, as well as the results of the amplification of DNA fragments from PCR. It also aims to obtain a method of isolating DNA from nibung plants with good quantity and quality in supporting the success of PCR-based amplification.

\section{MATERIALS AND METHODS}

Data collection was conducted at Teluk Pambang Village, Bantan, Bengkalis District, Riau Province, Indonesia. Sample collected from the field were then examined for the molecular characterization. This research has been carried out using a purposive sampling technique that is by directly observing the characteristics of nibung plants, then analyzing the results of molecular characterization.

The implementation of molecular character analysis is carried out in several stages of activities, namely: sample collection, DNA Isolation, DNA amplification, and DNA electrophoresis. Firstly, sample collection conducted by Nibung leaf sample (fresh leaf sample) collected. The leaves used are leaves taken from nibung plant habitat, namely from Bengkalis Regency. Leaf samples taken are fresh and healthy leaves, and are free of fungus or other pathogens. After the sample is collected, it is put in a plastic bag, then taken to the laboratory for DNA isolation. Secondly, DNA isolation was carried out using the Doyle and Doyle method [2] using liquid nitrogen and through dry storage in silica gel. The leaves are crushed using a mortar with the addition of $400 \mu \mathrm{l}$ extraction buffer until smooth and another $500 \mu \mathrm{l}$ extraction buffer is added. The extracted product was put in Eppendorf $2.0 \mathrm{ml}$ size. Subsequently incubated in the bath at a temperature of $65^{\circ} \mathrm{C}$ for 30 minutes and every 5 minutes the microtubes are turned upside down to help the lysis process. Furthermore, the mixture was removed from the bath and allowed to stand for 2 minutes at room temperature, then added $1000 \mu \mathrm{l}$ of the mixture of Khisam (Chloroform: Isoamilalkohol) with a ratio of 24: 1. Then vortex for 2-5 minutes, and continued with the centrifuge process for 10 minutes at speed of $12000 \mathrm{rpm}$. After centrifugation, it will separate between the supernatant at the top and chlorophyll and other compounds at the bottom. DNA is in the supernatant. The supernatant formed is pipetted and transferred to a new microtube.

Furthermore, the supernatant added sodium acetate $\left(\mathrm{CH}_{3} \mathrm{COONa}\right)$ as much as $1 / 10$ of the supernatant volume. Then added $2.5 \mathrm{x}$ absolute ethanol from the volume of the mixture in the tube. Then centrifuged at $12000 \mathrm{rpm}$ for 10 minutes to precipitate DNA. The liquid in the tube is discarded and the DNA deposits are washed with $70 \%$ ethanol then centrifuged again for 5 minutes and the liquid is discharged again. So that only the DNA deposits remain. The DNA precipitate was then dried in an oven at $50^{\circ} \mathrm{C}$ for 10 minutes. After drying, the DNA deposits are redissolved with 50 TE buffer containing RNase. Finally, DNA is incubated at $37^{\circ} \mathrm{C}$ for 30 minutes and ready to be used for further processing.

DNA amplification was carried out according to the method of Williams, et al. (1990) [3]. The primers used are primers that have been selected, namely GTGAGGCGTC nucleotide sequences and TCGTGCGGGT nucleotide sequences. The final volume of the reaction mixture is $25 \mu \mathrm{l}$ with a reaction composition of $2.5 \mu 110 \times$ PCR buffer; $1.5 \mu 1$ MgCl2 (25 mM); $0.5 \mu l$ dNTPs mix (10 mM), $2.5 \mu$ Primer $(5 \mathrm{pmol} / \mathrm{ul}) ; 0.2 \mu \mathrm{l}$ Taq DNA Polymerase; $16.8 \mu \mathrm{lddH} 20$ and $1 \mu \mathrm{l}$ printed DNA (10 ng/ $\mu \mathrm{l})$. The PCR used was MJ Research PCT1000. PCR conditions are as 
follows: initial denaturation at $94^{\circ} \mathrm{C}$ for 4 minutes, and followed by 35 thermal cycles consisting of 1 minute $94^{\circ} \mathrm{C}$ for denaturation processes, 1 minute $36^{\circ} \mathrm{C}$ for primary attachment (annealing), 2 minutes $72^{\circ} \mathrm{C}$ for DNA extension (extension) and a final extension at $72^{\circ} \mathrm{C}$ for 5 minutes. The reaction is repeated 44 times, bringing the total to 45 cycles.

DNA electrophoresis is prepared $1 \%$ agarose gel (1 gram agarose in $100 \mathrm{ml}$ aquadest heated in the microwave) and added 0.5x TBE buffer (Tris HCl-Boric acid-EDTA), then transferred to the mold. After the agarose gel solidifies, it is then inserted into an electrophoresis tank containing 0.5x TBE buffer. As much as $10 \mu \mathrm{l}$ of PCR product was added with $2 \mu$ loading dye and mixed thoroughly then put into a gel well. All samples were carried out in the same way. As a comparison, standard DNA (100 bp ladder) is also included. Next, the DNA sample of the PCR product in agarose gel is run with a 90volt for approximately 1.5 hours. After that, agarose gel was stained in a solution of ethidium bromide $(10 \mathrm{mg} / \mathrm{l})$ for 10 minutes and then washed with water for 20-30 minutes. Agarose gel was then visualized with the Chemidoc Gel System.

Data collected from the molecular characterization of nibung plant, consisting of a DNA isolation method, the factors that affect the process of DNA isolation, and the result of the amplification of DNA fragment from PCR. Qualitative data analysis was done in the molecular characterization study, quantitative data analysis was done for the measurement of DNA analysis. For scoring, 1 was given for the presence of the band, 0 was for the absence of the band. Those data were compiled and also presented descriptively and also with the figure.

\section{RESULTS AND DISCUSSION}

The results of DNA isolation of nibung plants that have been carried out using the modified Doyle and Doyle method show the size of DNA obtained in large size (high molecular weight DNA). In this case, the Nibung plant DNA isolation procedure applied has been able to produce large-sized DNA that is not degraded during the DNA extraction and purification process, and can be cut with restriction enzymes. The DNA bands profile can be seen in Figure 1. Based on Figure 1, it can be seen that the results of DNA testing for nibung plants indicate that the DNA isolation method used has produced different DNA sizes. The size of DNA can be seen from the distance of the bands produced by loading wells, after electrophoresis.

The results of DNA isolation need to be tested again to determine the quality of DNA that has been isolated. This is very important to be done to find out how pure DNA has been isolated so that amplification can be carried out at the next research stage. The next stage of the research was a purification and DNA amplification of nibung plants which had been isolated in the previous stage. After that, the primary selection stage for the PCR DNA of the nibung plant was carried out. The effectiveness of DNA isolation is one of the initial stages and is very important for the supply of DNA material for the next stage.

The results of DNA isolation were further quantified to see its concentration and purity. The concentration and purity of DNA from each isolation were tested using nanodrop spectrophotometers at wavelengths of $260 \mathrm{~nm}$ and $280 \mathrm{~nm}$. DNA purity was determined based on A260/A280 comparison values. From the DNA isolation process that has been carried out, obtained DNA with a large enough concentration, with the concentration of nucleic acid spectrophotometer results reached $2840.9 \mathrm{ng} / \mu \mathrm{l}$

The pattern of the Nibung DNA band produced is followed by the presence of a smear section below the DNA band. The formation of smears when electrophoresis due to DNA has undergone degradation and the presence of other compounds that are leftover from the extraction of DNA. DNA purity is a very important factor because DNA isolation is the initial stage for the provision of material for further analysis activities. Often the isolated DNA still contains protein compounds or other secondary metabolic compounds that can inhibit enzymatic effectiveness of digestion. DNA purification pattern with two times (Phenol Chloroform: Isoamyl Alcohol) conducted on the modified Doyle and Doyle method applied to nibung plants is very 
effective in removing various compounds that affect the process of DNA isolation such as protein, polysaccharides, and phenols.

The quality of DNA from isolation can be influenced by several factors such as the condition of the leaf sample used, the length of time of grinding, the phenolic content of the sample, the process of taking the supernatant solution and others. The quality of the isolated DNA of plants linked to the tissue types, and the way the sample was conserved and manipulated [4]; [5].

In DNA isolation of this study, these factors were seen to significantly affect the quality of the DNA produced, marked by the number of smear fragments. Also, DNA fragments produced from the isolation process are large, which indicates the large concentration of DNA produced. Evidenced by the concentration of nucleic acid spectrophotometer results reached 2840.9 $\mathrm{ng} / \mu 1$. Although many DNA bands smear, they still have clear DNA bands. Overall, the DNA isolation method based on the modified Doyle Doyle method in this study is applicable to the nibung plant.

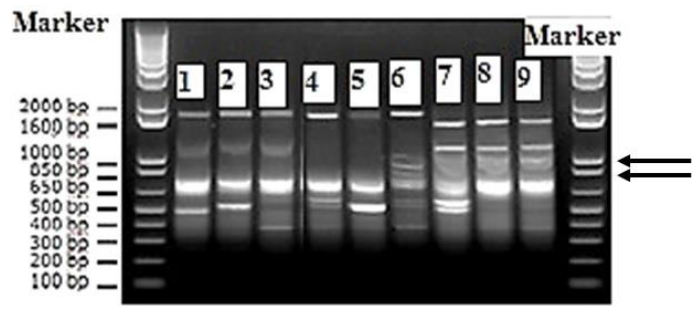

Figure 1. The profile of Nibung DNA ( $O$. tigillarium), smear DNA marked by the arrow symbol

Visualization of the DNA extraction results of nibung plants shows that there are a band of DNA pattern that look thin, faint, or smear. The profile of the total genomic DNA band shows the thickness and intensity of the smears which varies. This is due to the presence of polysaccharide compounds and secondary metabolites that are still left in the stock DNA. This fact in line with [6]; [7] that state that high endogenous levels of polyphenols and polysaccharides affect the isolation of good quantity and good quality of DNA. This factor is important for studying the molecular characterization of plants, for example, palm species [4], cotton [8], plants with a high content of secondary metabolites, based on leaves of Mimosa tenuiflora [9], maize [10], Arecaceae [11].

Contaminant compounds that can interfere with PCR reactions such as polysaccharides and secondary metabolites. These polysaccharides will settle together with nucleic acids. This is in line with the results of research by Varma et al. 2007 [12], and [13], that the problem that is often encountered in almost all stages of DNA isolation is the presence of contaminants such as DNA, proteins, polysaccharides, polyphenols and non-nuclear DNA. Other factors that affect the quality of DNA are the occurrence of DNA fragmentation or fragmentation during the extraction process and the remaining remnants of the extraction material. According to Lucas et al. 2019 [4] and Schori et al. 2013 [5], conclude that the rest of the extraction material such as phenol, and chloroform which is also precipitated will affect the quantity and quality of DNA. On the other hand, the types of tissues are giving implications for studies in the optimized protocol to isolate high-quality genomic DNA from palm species. Plants contain many secondary metabolites, including phenols, glycoproteins, and polysaccharides, which is linked to DNA extraction and PCR process. Furthermore, in the PCR process, the efficiency of PCR amplification does not occur at $00 \%$. This happens because the target template is too large, the amount of DNA polymerase is limited, and the possibility of annealing the target strand.

\section{CONCLUSION}

In conclusion, there are some characteristics of the molecular characters of Riau's Mascot Flora (O. tigillarium), namely: DNA isolation method, DNA purification, and several factors that influence of DNA quality of Nibung plant. In this case, the Doyle Doyle method is an ideal method for DNA isolation of this plant. In this study, the leaves sample conditions, grinding process, phenolic content, the process of taking the supernatant were seen to significantly affect the quality of the DNA of the Nibung plant. Therefore, in this case, the researcher highly recommends this method to 
be applied in conducting research that is in line with this research for future development.

\section{ACKNOWLEDGMENTS}

Directorate of Research and Public Service, Directorate-General of Research and Development for the Strengthening of the Ministry of Research, Technology and Higher Education, through Research and Public Service Institutes of Universitas Islam Riau (LPPM UIR) Pekanbaru for funding this research.

\section{REFERENCES}

[1] Desti, and Mellisa.Morphological characterization of mascot flora of Riau Province (Oncosperma tigillarium) and its development as teaching material for Plant Botany subjects. Bioterdidik Journal FKIP Universitas Lampung, 2017, Vol. 5 No. 7.

[2] Doyle, J.J., and J.L. Doyle. Isolation of plant DNA from fresh tissue. Focus, 1990,12: $13-15$.

[3] Williams, J.K., A.R. Kubelik., K.J. Livak, J.A. Rafalski and S.V. Tingey. DNA polymorphism amplified by arbitrary primers is useful as genetic markers. Nucleic Acid Research,1990, 18 (22): 6531-6535.

[4] Lucas MS, C de S Carvalho, GB Hypolito, MC Côrtes. Optimized protocol to isolate high-quality genomic DNA from different tissue of palm species. Hoehnea , 2019,46(2).

[5] Schori M, M Appel, AR Kitko, AM Showalter. Engineered DNA polymerase improves PCR results for plastid DNA. Applications in Plant Sciences ,2013, 1(2): 1200519.

[6] Dash PK. Erratum to: high-quality RNA isolation from polyphenol-, a polysaccharide- and protein-rich tissue in lentil (Lens culinaris). Biotech 3 ,2013, 529.

[7] Kalbande BB, Patil AS, Chakrabarty PK. An efficient, simple and high throughput protocol for cotton genomic DNA isolation. J. Plant Biochem. Biotechnol. 25 , 2016, 437-441.
[8] Ali Q, Salisu IB, Raza A, Shahid AA, Rao AQ, Husnain T. A modified protocol for rapid DNA isolation from cotton (Gossypium spp). MethodsX 6 , 2019, 259-264.

[9] Arruda SR, Pereira DG, Silva-Castro MM, Brito MG, Waldschmidt AM. An optimized protocol for DNA extraction in plants with a high content of secondary metabolites, based on leaves of Mimosa tenuiflora (Wild) Poir (Leguminosae). Genet. Mol. Res. 16 , 2017, 3 .

[10] Abdel-Latif A, Osman G. Comparison of three genomic DNA extraction methods to obtain high DNA quality from maize. Plant Methods 13, 2017, 1.

[11] Lanes ECM, Nick C, Kuki KN, Freitas RD, Motoike SY. Genomic DNA isolation of Acrocomia aculeate (Arecaceae) from leaf and stipe tissue samples for PCR analysis. Genetics and Molecular Research 12, 2013, 39053911.

[12] Varma A, Padh H, Shrivastava H. Plant genomic DNA isolation: an art or a science. Biotechnol. J. 2 , 2007, 386-392.

[13] Choudhary P, Das S, Chakdar H, Singh A, Goswami SK, Saxena AK. Rapid high throughput template preparation (rHTTP) method: a novel cost-effective method of direct PCR for a wide range of plants. BMC Biotechnology , 2019, 19-69. 